\title{
Phytochemical characterization of Borago officinalis L. and Centaurea cyanus L. during flower development
}

\author{
L. Fernandes ${ }^{\mathrm{a}, \mathrm{b}, \mathrm{c}}$, J.A. Pereira ${ }^{\mathrm{a}}$, J.A. Saraiva ${ }^{\mathrm{c}}$, E. Ramalhosa ${ }^{\mathrm{a}, *}$, S. Casal ${ }^{\mathrm{b}, *}$ \\ ${ }^{a}$ Centro de Investigação de Montanha (CIMO)/School of Agriculture, Polytechnic Institute of Bragança, Campus de St ${ }^{g}$ Apolónia, 5300-253 Bragança, Portugal \\ ${ }^{\mathrm{b}}$ LAQV@REQUIMTE/Laboratory of Bromatology and Hydrology, Faculty of Pharmacy, Porto University, Rua Jorge Viterbo Ferreira, 228, 4050-313 Porto, Portugal \\ c Organic Chemistry, Natural Products and Agrifood (QOPNA) - Chemistry Department, University of Aveiro, Campus Universitário de Santiago, 3810-193 Aveiro, \\ Portugal
}

\section{A R T I C L E I N F O}

\section{Keywords:}

Carotenoids

Edible flowers

Fatty acids

Flower development

Free sugars

Organic acids

Tocopherols

Vitamin E

\begin{abstract}
A B S T R A C T
The present work details the nutritional and chemical compositions of borage and centaurea, at three flowering stages. Water was the main constituent, followed by total dietary fiber. Both flowers showed statistically different $(p<0.05)$ nutritional and chemical profiles, although in both, polyunsaturated fatty acids (PUFAs) (mainly linoleic and $\alpha$-linolenic acids), free sugars (3.9-28.9\% dw as fructose, glucose, and sucrose), tocopherols (with the major contribution of $\alpha$-tocopherol from 1.24 to $2.75 \mathrm{mg} / 100 \mathrm{~g} \mathrm{dw}$ ), carotenoids $(0.2-181.4 \mathrm{mg} / 100 \mathrm{~g}$ $\mathrm{dw}$, mainly as lutein), and organic acids (6.1-14.4 g/100 g dw, mainly malic, succinic, and citric acids) were quantified. Concerning flowering, significant differences $(p<0.05)$ were found for some components, particularly carotenoids; however, no specific trend was observed in either of the two flower species. Thus, the present study shows that each flower species, as well as their flowering stages, may have different phytochemical and nutritional compositions.
\end{abstract}

\section{Introduction}

The commercial value of edible flowers is increasing in the food sector, mostly due to consumer' interest in natural products, new ingredients with potential health benefits, and the aesthetic benefits of their use in food and beverages (colors, textures, and flavor) (GonzálezBarrio, Periago, Luna-Recio, Javier, \& Navarro-González, 2018; Mlcek \& Rop, 2011). Flowers may be consumed as buds and/or the whole flower, or only petals, depending on the flower species. The period of flower development from mature bud to open flower encompasses one of the most active growth periods in the entire developing process of plants (Reid, 2005). During this process, plants undergo different stages, in which a variety of physiological, biochemical and structural processes occur (Chen, Zhu, Guo, Zhang, \& Zhang, 2012; Çirak, Janulis, \& Ivanauskas, 2007; Collier, 1997). Sometimes the chemical changes that happen during flower development affect their nutritional and beneficial health properties (Dar, Tahir, \& Ahmad, 2014; Shahri, Tahir, Islam, \& Bhat, 2011). Thus, consumers are likely to eat flowers of different compositions, according to the part of the flower or development stage. Hence, understanding changes in chemical and nutritional composition during flower development can help to enhance their quality and bioactive potential, and thus, increase edible flowers' commercial value. However, publications on the chemical and nutritional characterization of edible flowers during flower development are limited. A small number of studies have focused primarily on protein, anthocyanins, sugars and enzymes in rose species (Rosa hybrida, $R$. damascena Herrm., and R. bourboniana Desp.) (Dafny-Yelin et al., 2005; Sood, Vyas, \& Nagar, 2006), bioactive compounds in rosemary (Rosmarinus officinalis L.) (Del Baño et al., 2003), carbohydrates and anthocyanin pigments in nasturtium flowers (Tropaeolum majus L.) (Silva, 2012), the chemical composition of Opuntia ficus-indica (L.) Mill. and $O$. stricta Haw. flowers (Ammar, Ennouri, Bali, \& Attia, 2014), and physiological and biochemical changes in carnations (Dianthus chinensis L.) (Dar et al., 2014).

In particular, centaurea and borage are two important edible flowers that have been sold in different areas, and includes examples, such as Ervas Finas ${ }^{\oplus}$, BloomBites ${ }^{\oplus}$, Meadowsweet Flowers ${ }^{\oplus}$, and Petite Ingredient ${ }^{\oplus}$. These are used in culinary preparation by both chefs and consumers.

Centaurea (Centaurea cyanus L.), also called 'blue cornflower' or 'bachelor's button', is a plant native to Europe. Its flowers have no fragrance, but they have a sweet-to-spicy clove-like flavor. Centaurea petals are ideal for mixing with other flowers to make dishes more attractive, for sprinkling over salads (Chaitanya, 2014), or to be used as

\footnotetext{
* Corresponding authors.

E-mail addresses: elsa@ipb.pt (E. Ramalhosa), sucasal@ff.up.pt (S. Casal).
} 
an ingredient in tea (Chaitanya, 2014). Dried flowers have been proven to contain a long list of medicinal properties, such as being anti-inflammatory, skin cleansing, assisting regulating digestion and kidney, gall bladder, liver and menstrual disorders, and increasing immunity (Chaitanya, 2014; Pirvu, Dragomir, Schiopu, \& Mihul, 2012).

Borage (Borago officinalis L.) is an annual herb, that is native to some parts of the Mediterranean region, and is cultivated for medicinal and culinary uses, but primarily for borage seed oil (Asadi-Samani, Bahmani, \& Rafieian-Kopaei, 2014). Borage flowers are blue and on rare occasions appear white or pink (Asadi-Samani et al., 2014). Petals have a cucumber-like taste and the stamens add a hint of sweetness. The flowers are used in vegetable dishes and fruit salads, to garnish soups or decorate desserts (Husti, Cantor, Buta, \& Horţ, 2013), as well as in ice cubes (Husti et al., 2013).

To the authors' best knowledge, no studies on the phytochemical modifications during borage and centaurea flower development have been conducted. Thus, the present study was conducted to determine the evolution and changes that occur in the nutritional and chemical composition (fatty acids, free sugars, vitamin E, carotenoids and organic acids) of these two edible flowers, along with their flower development (tight and mature buds, and fully open flowers). The main objective of doing so is to gather important scientific information for the academic community, and for those with an interest in the subject such as flowers producers, and for the community in general. By valorizing these products, the research can contribute to the popularization of flowers as food or supplements for food, and highlight their use to cosmetics and pharmaceutical industries.

\section{Material and methods}

\subsection{Plant material}

The flowers of B. officinalis and C. cyanus were collected from the greenhouse of the School of Agriculture of the Polytechnic Institute of Bragança (Bragança, Portugal). Once harvested, flowers at different stages of development were immediately transported to the laboratory under refrigeration. Flower development was divided into three stages (Fig. 1): stage one (tight bud stage) - closed bud flower, showing some petal color at the tip of the bud end; stage two (mature bud stage) closed bud flower, showing the color of petals in their entire surface; stage three (fully open) - completely opened flower, without symptoms of senescence. Furthermore, petals (true petals, not bracts) were also picked, because they are often the sole parts of flowers used for culinary purposes.
Flowers were evaluated for their moisture content before being freeze-dried. All chemical analyses were performed using the freeze dried samples, with the results presented in dry weight (dw) or converted to fresh weight (fw).

\subsection{Moisture, dietary fiber, and nutritional composition}

The moisture, ash, fat, carbohydrates, and dietary fiber of each sample were analyzed using AOAC procedures (1995) and expressed as $\mathrm{g} / 100 \mathrm{~g}$ fresh weight ( $\mathrm{fw}$ ). Moisture content was determined by drying the sample to a constant weight at $105^{\circ} \mathrm{C}$; ash content was measured by calcination at $550^{\circ} \mathrm{C}$ for at least $2 \mathrm{~h}$, until achieving white ashes. The protein content of samples was estimated using the macro-Kjeldahl method, with a conversion factor of 6.25 , as per Sotelo, López-García, and Basurto-Peña (2007) and Rop, Mlcek, Jurikova, Neugebauerova, and Vabkova (2012). Lipids were determined by extracting a known mass of powdered sample with petroleum ether, with $0.01 \%$ BHT $(2,6-$ di-tert-butyl-4-methylphenol) to prevent oxidation, using a Soxhlet apparatus. Dietary fiber was determined by an enzymatic-gravimetric method based on AOAC official method No. 985.29 (AOAC, 2003).

Free sugars were extracted by following the procedure described by Barros, Oliveira, Carvalho, and Ferreira (2010). Sugars were analyzed in a Jasco integrated high performance liquid chromatographic system (Tokyo, Japan), equipped with a PU-980 intelligent pump and a refractive index detector (Gilson, USA). Separation was achieved with a SUPELCOGEL Ca column $(30 \mathrm{~cm} \times 7.8 \mathrm{~mm}$ I.D., Supelco, USA), operating at $80^{\circ} \mathrm{C}$, with ultra-pure water at a flow rate of $0.5 \mathrm{~mL} / \mathrm{min}$ as eluent. Sugar identification was made by comparing the retention times of sample peaks with standards. Quantification was performed by the external standard method with individual calibration curves for each sugar at concentrations ranging from 0.5 to $10 \mathrm{mg} / \mathrm{mL}$. The results were expressed as $\mathrm{g} / 100 \mathrm{~g} \mathrm{dw}$.

\subsection{Analysis of lipids' minor components}

\subsubsection{Lipids compounds extraction}

Lipid extraction for compositional analysis was performed according to the method described by Cruz et al. (2013). A $250 \mathrm{mg}$ portion of a lyophilized sample was weighted in a plastic tube. Two internal standards solutions, tocol $(20 \mu \mathrm{L} ; 1 \mathrm{mg} / \mathrm{mL})$ for vitamin $\mathrm{E}$ quantification, and triundecanoin $(200 \mu \mathrm{L} ; 1 \mathrm{mg} / \mathrm{mL})$, for total fatty acids quantification, were added. Following on, two antioxidants, BHT $(20 \mu \mathrm{L}, 10 \mathrm{mg} / \mathrm{mL}$ in methanol) and ascorbic acid $(50 \mathrm{mg})$, were also added. Propan-2-ol $(1.6 \mathrm{~mL})$ and cyclohexane $(2.0 \mathrm{~mL})$ were mixed and

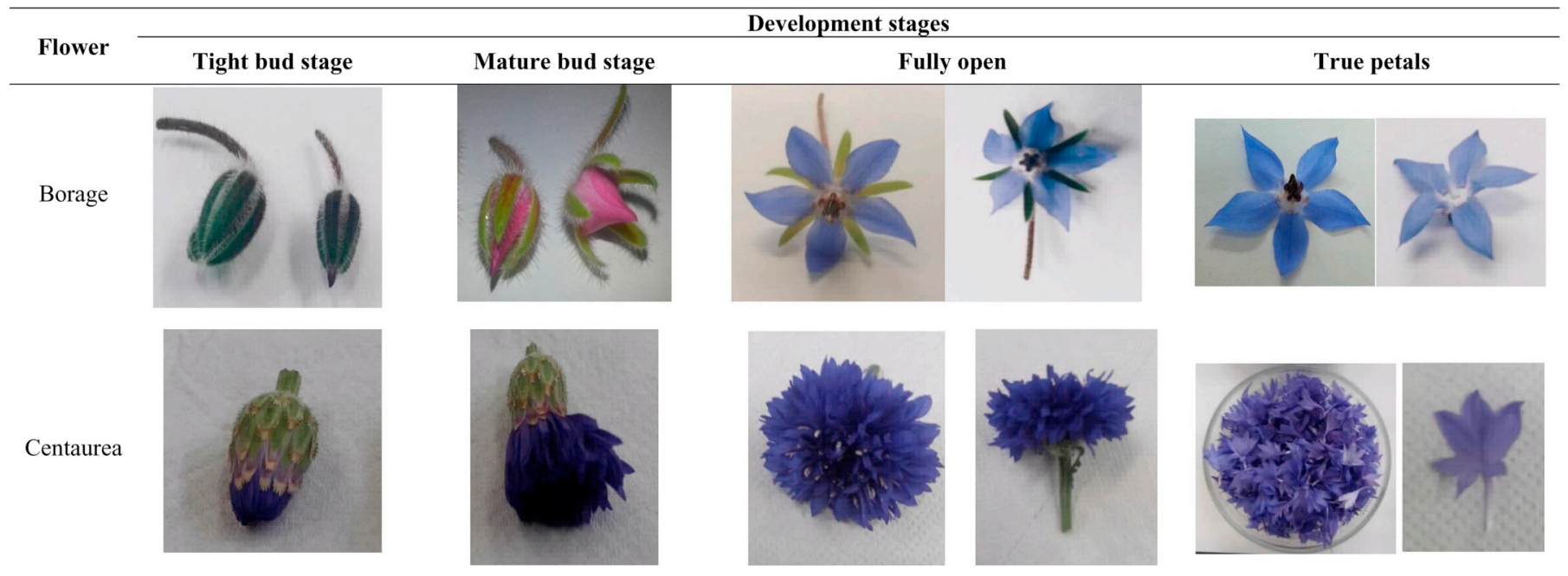

Fig. 1. Petals and three flowering stages of borage (Borago officinalis) and centaurea (Centaurea cyanus). 
agitated briefly by vortexing and kept overnight under refrigeration $\left(4{ }^{\circ} \mathrm{C}\right)$. The non-lipidic fraction was removed by washing with $2.5 \mathrm{~mL}$ of a $1 \% \mathrm{NaCl}$ solution $(\mathrm{m} / \mathrm{v})$, followed by agitation by vortexing and centrifugation ( $3000 \mathrm{rpm}, 5 \mathrm{~min}$; Heraeus Sepatech, Germany). The organic phases were dehumidified with anhydrous sodium sulfate and divided into two portions. For fatty acid analysis, the solvent was evaporated under a nitrogen stream $\left(60^{\circ} \mathrm{C}\right)$. Hydrolysis was performed with $1.5 \mathrm{~mL}$ of $\mathrm{KOH}\left(0.5 \mathrm{M}\right.$ in methanol) at $100^{\circ} \mathrm{C}(10 \mathrm{~min})$ in a dry heating block (Stuart SBH200D/3, Staffordshire, UK). After reaching room temperature, methylation was completed by the addition of $1.5 \mathrm{~mL}$ of $\mathrm{BF}_{3}(14 \%$ in methanol) and heated for a further $30 \mathrm{~min}$ at $100{ }^{\circ} \mathrm{C}$. After cooling, $1 \% \mathrm{NaCl}(\mathrm{m} / \mathrm{v})(2.5 \mathrm{~mL})$ and $n$-hexane $(2 \times 2 \mathrm{~mL})$ were added and the mixture was mixed by vortexing, followed by centrifugation ( $3000 \mathrm{rpm}, 5 \mathrm{~min}$ ). The supernatant was transferred to a tube with anhydrous sodium sulfate, followed by centrifugation at $5000 \mathrm{rpm}$ for $5 \mathrm{~min}$. A supernatant portion $(2 \mathrm{~mL})$ was directly transferred to a clear glass vial (Supelco, Sigma, Bellfonte, USA). The solvent was evaporated under a nitrogen stream $\left(60^{\circ} \mathrm{C}\right)$, re-suspended with heptane $(1 \mathrm{~mL})$, and the solution mixed in a vortex. This solution was analyzed in a gas chromatograph for fatty acid analysis, as detailed below. The remaining lipid extract (half of the re-suspended extract) was transferred to an amber glass vial. The solvent was evaporated under a gentle nitrogen stream $\left(40^{\circ} \mathrm{C}\right)$, re-suspended in about $600 \mu \mathrm{L}$ of $n$-hexane (HPLC grade) and placed in the HPLC autosampler for vitamin $\mathrm{E}$ and carotenoids quantification.

\subsubsection{Fatty acids}

Fatty acids were analyzed according to the method described by Amaral, Casal, Pereira, Seabra, and Oliveira (2003), with slight modifications. The temperatures of the injector and detector were 250 and $270{ }^{\circ} \mathrm{C}$, respectively. Separation was achieved on a $100 \mathrm{~m} \times 0.25 \mathrm{~mm}$ i.d. Select-FAME column (0.19- $\mu \mathrm{m}$ film; Agilent, Santa Clara, USA). Helium was used as carrier gas at an internal pressure of $180 \mathrm{kPa}$. Fatty acids identification (C11:0-C22:6) was accomplished by comparing the relative retention times of FAME peaks with the standards gained from a diverse range of suppliers, from literature data, and confirmed by GC-MS on a Agilent chromatograph 7890A with a 5977B MSD (MS source $-230{ }^{\circ} \mathrm{C}$; MS QUAD 150 ; aux $\left.280^{\circ} \mathrm{C} ; \mathrm{m} / \mathrm{z} 30-800\right)$, using the NIST/EPA/NIH Mass Spectral Library (NIST 14). For quantification purposes, FID peaks were corrected using the response factors obtained with standard FAME solutions. The fatty acids results were calculated on a relative percentage basis.

\subsubsection{Vitamin $E$ and carotenoids}

Separation was achieved by normal-phase HPLC, based on the method described by Cruz and Casal (2018). The liquid chromatograph consisted of a Jasco integrated system (Easton, USA) equipped with an autosampler (AS-2057 Plus), a PU-980 intelligent pump, and a multiwavelenght DAD (MD-910), recording at $450 \mathrm{~nm}$ for carotenoids, connected to a fluorescence detector (FD) (FP-2020 Plus; $\lambda_{\text {excitation }}=290 \mathrm{~nm}$ and $\lambda_{\text {emission }}=330 \mathrm{~nm}$ ) for vitamin E. Chromatographic separation was achieved on a Luna Silica column $(100 \mathrm{~mm} \times 3 \mathrm{~mm} ; 3 \mu \mathrm{m})$ (Phenomenex, USA), operating at constant room temperature $\left(23^{\circ} \mathrm{C}\right)$, with a gradient of $n$-hexane and 1,4-dioxane at a flow rate of $1.0 \mathrm{~mL} / \mathrm{min}$. The compounds were identified by chromatographic comparisons using authentic standards. Tocopherols and tocotrienols ( $\alpha-, \beta-, \gamma$-, and $\delta$-) were acquired from Supelco (USA) and Larodan $\mathrm{AB}$ (Sweden). Carotenoids standards (all-trans- $\beta$-carotene and lutein) were sourced from Sigma Aldrich (USA). Identified tocopherols and carotenoids were quantified by the internal standard method, reported on a dw basis.

The total carotenoids content was estimated according to the method described by Aquino-Bolaños et al. (2013). One gram of frozendried powder of each sample was extracted twice using a $20 \mathrm{~mL}$ acetone:hexane solution $(1: 1, \mathrm{v} / \mathrm{v})$. Both extracts were put into a separation funnel: $200 \mathrm{~mL}$ distilled water was then added to eliminate acetone.
The acetone-free phase was mixed with anhydrous sodium sulfate $(5 \mathrm{~g})$ to eliminate any residual water, and the remaining solution filtered and completed to $100 \mathrm{~mL}$ with hexane. Carotenoids content was determined by reading the absorbance at $450 \mathrm{~nm}$ and comparing the results with a $\beta$-carotene calibration curve $(0.22-8.8 \mu \mathrm{g} / \mathrm{mL})$. Results were expressed as $\mathrm{mg} \beta$-carotene equivalent/100 $\mathrm{g} \mathrm{dw}$.

\subsection{Organic acids}

The organic acids in the edible flowers were determined by gas chromatography, after methylation, following the procedure described by Sharma et al. (2016) and Kumar, Sharma, Bhardwaj, and Thukral (2017), with minor modifications. The analytical column used was a HP-5MS $(30 \mathrm{~m} \times 0.25 \mathrm{~mm}$ i.d. $\times 0.25 \mu \mathrm{m}$ thickness ultra-inert capillary column, by Agilent Technologies). Mass spectra were obtained by electron ionization (EI) at $70 \mathrm{eV}$, in full scan mode, with a spectrum range of ion mass captured between 25 and $400 \mathrm{~m} / \mathrm{z}$, and an average of 3.5 scans/s (sample rate of 2). The mass spectra were evaluated using Enhanced ChemStation software (Version F.01.03.2357, Agilent Technologies). Individual standards of citric, levulinic, fumaric, succinic, malic, salicylic, hydroxycinnamic, malonic, oxalic, tartaric and benzoic acids - all supplied by Sigma Aldrich (Germany) - were derivatized under sample conditions. Quantification was based on individual calibration curves, using specific $\mathrm{m} / \mathrm{z}$ for each compound, as detailed in Kumar et al. (2017).

\subsection{Statistical analysis}

The statistical analysis was performed using SPSS software, Version 18.0 (SPSS Inc., Chicago, USA). The normality of the data and homogeneity of the variances were confirmed by Shapiro-Wilk and Levene's tests, respectively. To verify if significant differences $(p<0.05)$ existed between samples, an analysis of variance (ANOVA) or ANOVA Welch was performed, depending on the existence or non existence of homogeneity of variances, respectively. When significant differences were detected between treatments, Tukey's honest significant difference test (if variances in different groups were identical) or the GamesHowell test (if they were not) were performed.

\section{Results and discussion}

\subsection{Moisture, dietary fiber, and nutritional composition}

The moisture, dietary fiber, and nutritional compositions of borage and centaurea at three flowering stages are detailed in Table 1 . Water was the main constituent in both flowers at all stages $(73.7-90.5 \mathrm{~g} /$ $100 \mathrm{~g} \mathrm{fw}$ ), followed by total dietary fiber (3.84-17.2 g/100 g fw), while lipids were minor constituents $(0.41-1.13 \mathrm{~g} / 100 \mathrm{~g} \mathrm{fw})$.

When comparing both flowers, borage always presented significantly higher $(\mathrm{p}<0.05)$ moisture content $(>85 \mathrm{~g} / 100 \mathrm{~g} \mathrm{fw})$ than centaurea $(>73 \mathrm{~g} / 100 \mathrm{~g} f \mathrm{f})$. The same was observed for ash values (1.74-2.05 vs. $1.20-1.56 \mathrm{~g} / 100 \mathrm{~g} \mathrm{fw}$, respectively). On the other hand, centaurea always presented significantly higher amounts $(\mathrm{p}<0.05)$ of total dietary fiber $(14.8-17.2 \mathrm{~g} / 100 \mathrm{~g} \mathrm{fw})$ than borage (3.84-6.74 g/ $100 \mathrm{~g} \mathrm{fw})$. In general, these values were similar to selected vegetables: asparagus (moisture 79.34-92.20, proteins 3.62-4.83, fat $0.33-0.90 \mathrm{~g}$ / $100 \mathrm{~g} \mathrm{fw}$ ) (Ferrara et al., 2011), white cabbage (moisture 91.8, proteins 1.4, fat 0.4 , dietary fiber $2.4 \mathrm{~g} / 100 \mathrm{~g} \mathrm{fw}$ ) and cucumber (moisture 95.1, proteins 1.4 , fat 0.6 , dietary fiber $0.7 \mathrm{~g} / 100 \mathrm{~g} \mathrm{fw}$ ) (Instituto Nacional de Saúde Doutor Ricardo Jorge, 2010).

Regarding centaurea, our results expressed in dry weight (data not shown) were similar to those reported by Rop et al. (2012) for fully open flowers (protein $6.9 \mathrm{~g} / 100 \mathrm{~g} \mathrm{dw}$, in both studies), and the results of Pires, Dias, Barros, and Ferreira (2017) for true petals of this species (protein 5.8 vs $8.5 \mathrm{~g} / 100 \mathrm{~g} \mathrm{dw}$ ).

During the flowering stage (from tight bud to fully open flower), the 
Table 1

Composition in moisture, nutrients and total dietary fiber of borage and centaurea at three flowering stages plus isolated petals ( $\mathrm{g} / 100 \mathrm{~g}$ fw).

\begin{tabular}{|c|c|c|c|c|c|c|c|c|}
\hline & \multicolumn{4}{|l|}{ Borage } & \multicolumn{4}{|l|}{ Centaurea } \\
\hline & Tight bud & Mature bud & Fully open & (Petals) & Tight bud & Mature bud & Fully open & (Petals) \\
\hline Moisture & $86.9 \pm 0.4^{\mathrm{a}, \mathrm{B}}$ & $85.3 \pm 1.8^{\mathrm{a}, \mathrm{B}}$ & $86.6 \pm 1.8^{\mathrm{a}, \mathrm{B}}$ & $90.5 \pm 0.4^{\mathrm{b}, \mathrm{B}}$ & $73.7 \pm 2.2^{\mathrm{a}, \mathrm{A}}$ & $76.3 \pm 1.2^{\mathrm{a}, \mathrm{A}}$ & $76.7 \pm 0.6^{\mathrm{a}, \mathrm{A}}$ & $80.5 \pm 0.7^{\mathrm{b}, \mathrm{A}}$ \\
\hline Ash & $2.02 \pm 0.14^{\mathrm{c}, \mathrm{B}}$ & $1.74 \pm 0.04^{\mathrm{b}, \mathrm{B}}$ & $2.05 \pm 0.11^{\mathrm{c}, \mathrm{B}}$ & $0.88 \pm 0.04^{\mathrm{a}, \mathrm{A}}$ & $1.56 \pm 0.06^{\mathrm{c}, \mathrm{A}}$ & $1.43 \pm 0.11^{\mathrm{b}, \mathrm{c}, \mathrm{A}}$ & $1.20 \pm 0.11^{\mathrm{a}, \mathrm{b}, \mathrm{A}}$ & $1.11 \pm 0.04^{\mathrm{a}, \mathrm{A}}$ \\
\hline Protein & $2.24 \pm 0.09^{\mathrm{b}, \mathrm{A}}$ & $2.62 \pm 0.10^{\mathrm{c}, \mathrm{B}}$ & $3.04 \pm 0.10^{\mathrm{d}, \mathrm{B}}$ & $0.89 \pm 0.02^{\mathrm{a}, \mathrm{A}}$ & $2.89 \pm 0.55^{\mathrm{b}, \mathrm{A}}$ & $1.78 \pm 0.28^{\mathrm{a}, \mathrm{A}}$ & $1.60 \pm 0.06^{\mathrm{a}, \mathrm{A}}$ & $1.66 \pm 0.24^{\mathrm{a}, \mathrm{B}}$ \\
\hline Lipid & $0.68 \pm 0.16^{\mathrm{a}, \mathrm{A}}$ & $0.56 \pm 0.02^{\mathrm{a}, \mathrm{A}}$ & $0.66 \pm 0.15^{\mathrm{a}, \mathrm{A}}$ & $0.41 \pm 0.08^{\mathrm{a}, \mathrm{A}}$ & $0.89 \pm 0.08^{\mathrm{a}, \mathrm{A}}$ & $1.13 \pm 0.20^{\mathrm{a}, \mathrm{B}}$ & $0.80 \pm 0.03^{\mathrm{a}, \mathrm{A}}$ & $0.86 \pm 0.16^{\mathrm{a}, \mathrm{B}}$ \\
\hline \multicolumn{9}{|l|}{ Soluble sugars } \\
\hline Sucrose & $3.55 \pm 0.53^{\mathrm{a}, \mathrm{B}}$ & $4.92 \pm 0.67^{\mathrm{a}, \mathrm{B}}$ & $3.86 \pm 0.75^{\mathrm{a}, \mathrm{B}}$ & $9.60 \pm 1.67^{\mathrm{b}, \mathrm{B}}$ & $1.45 \pm 0.15^{\mathrm{a}, \mathrm{A}}$ & $1.30 \pm 0.05^{\mathrm{a}, \mathrm{A}}$ & $1.33 \pm 0.06^{\mathrm{a}, \mathrm{A}}$ & $1.18 \pm 0.45^{\mathrm{a}, \mathrm{A}}$ \\
\hline Glucose & $5.12 \pm 0.44^{\mathrm{a}, \mathrm{B}}$ & $6.94 \pm 0.71^{\mathrm{b}, \mathrm{B}}$ & $5.96 \pm 0.75^{\mathrm{a}, \mathrm{b}, \mathrm{B}}$ & $8.85 \pm 0.15^{\mathrm{c}, \mathrm{B}}$ & $0.91 \pm 0.10^{\mathrm{a}, \mathrm{A}}$ & $2.10 \pm 0.04^{\mathrm{b}, \mathrm{A}}$ & $1.74 \pm 0.07^{\mathrm{b}, \mathrm{A}}$ & $7.30 \pm 0.46^{\mathrm{c}, \mathrm{A}}$ \\
\hline Fructose & $5.72 \pm 0.36^{\mathrm{a}, \mathrm{B}}$ & $7.86 \pm 0.87^{\mathrm{b}, \mathrm{B}}$ & $6.97 \pm 0.38^{\mathrm{b}, \mathrm{B}}$ & $10.4 \pm 0.30^{\mathrm{c}, \mathrm{B}}$ & $1.57 \pm 0.12^{\mathrm{a}, \mathrm{A}}$ & $2.49 \pm 0.04^{\mathrm{b}, \mathrm{A}}$ & $2.71 \pm 0.10^{\mathrm{b}, \mathrm{A}}$ & $3.43 \pm 0.40^{\mathrm{b}, \mathrm{A}}$ \\
\hline Total dietary fiber & $6.28 \pm 0.16^{\mathrm{c}, \mathrm{A}}$ & $6.74 \pm 0.05^{\mathrm{d}, \mathrm{A}}$ & $4.74 \pm 0.10^{\mathrm{b}, \mathrm{A}}$ & $3.84 \pm 0.03^{\mathrm{a}, \mathrm{A}}$ & $17.2 \pm 1.4^{\mathrm{b}, \mathrm{B}}$ & $14.8 \pm 0.8^{\mathrm{a}, \mathrm{B}}$ & $15.7 \pm 0.5^{\mathrm{a}, \mathrm{b}, \mathrm{B}}$ & $14.8 \pm 0.7^{\mathrm{a}, \mathrm{B}}$ \\
\hline
\end{tabular}

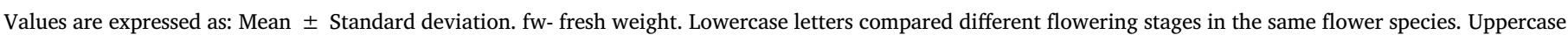
letters compared both flowers at the same flowering stage. Values with the same letter are not statistically different ( $p>0.05$ ).

nutritional composition trends for both flowers were different. Borage showed an increase in protein, while in centaurea, a decrease in ash and protein content was observed. Peiretti, Palmegiano, and Salamano (2004) reported a progressive decrease in crude protein content during the developmental stages of borage, specifically, $149 \mathrm{~g} / \mathrm{kg}$ dw for late vegetative stage to $138 \mathrm{~g} / \mathrm{kg}$ dw for late flower stage. In our work, the lipid content remained almost constant, while dietary fiber showed variable behavior, when both flowers were compared. These patterns are in line with literature results for other flowers, as in the case of the two Opuntia species at four stages of development reported by Ammar et al. (2014). The flowers of $O$. ficus-indica showed an increase in fat and a decrease in fiber content (three first stages of flowering), while in $O$. stricta, the opposite was detected (Ammar et al., 2014). Thus, each flower, at each flower development stage, showed a unique composition and nutritional value.

For both flowers studied, petals alone presented the highest moisture content when compared with the entire flower. In borage, the separation of petals from the flower represented a highly significant reduction in protein, lipids, and total dietary fiber, while in centaurea only minor changes were observed. To gain the highest protein content, borage should be consumed as a fully opened flower, while for centaurea the tight bud should be preferred. To obtain a higher fiber content, tight buds should be chosen.

Three free sugars were identified, namely, sucrose, glucose, and fructose. Fructose was the major sugar in both flowers at all flowering stages $(1.57-10.4 \mathrm{~g} / 100 \mathrm{~g} \mathrm{dw})$, except in centaurea petals, in which glucose dominated $(7.30 \mathrm{~g} / 100 \mathrm{~g} \mathrm{dw})$. Similar results were reported for other flowers by Guimarães, Barros, Carvalho, and Ferreira (2010) and Pires et al. (2017), who detected fructose as the main sugar in Rosa micrantha, dahlia, and centaurea petals. Borage presented higher values for all free sugars, which can likely be associated with its sweet, sensory attribute. Concerning different flowering stages and parts of the flower, petals showed the highest values of free sugars for both flowers, except for sucrose in centaurea. Different functions in flower development have been attributed to sugars, namely as an energy source (MoalemBeno, Tamari, Leitner-Dagan, Borochov, \& Weiss, 1997), osmotic regulators (Bieleski, 1993), and precursors of metabolic processes. During flower development (from tight bud to fully open flower), the sucrose and glucose remained constant in borage, while fructose increased from 5.72 to $6.97 \mathrm{~g} / 100 \mathrm{~g} \mathrm{dw}$. In centaurea, sucrose also remained constant, while glucose and fructose increased (from 0.91 to 1.74 and 1.57 to $2.71 \mathrm{~g} / 100 \mathrm{~g} \mathrm{dw}$, respectively). This may be related to the fact that sugar availability is an important signal during floral induction; in particular sucrose was described as a major photosynthetic product, and acts as a signal to control the timing of flowering (Cho, Pasriga, Yoon, Jeon, \& An, 2018; Tognetti, Pontis, \& Martinez-Noel, 2013). Moreover, its hydrolytic products (glucose and fructose), as well as their downstream metabolic intermediates, trehalose and trehalose-6phosphate, also act as control signals (Cho et al., 2018).

\subsection{Fatty acids}

The fatty acids profiles of borage and centaurea at three flowering stages are shown in Table 2, presented as individual, and grouped as total saturated fatty acids (SFA), monounsaturated fatty acids (MUFA), and polyunsaturated fatty acids (PUFA), together with the ratios of PUFA/SFA and $n-6 / n-3$. Nineteen fatty acids were identified and quantified. The major fatty acid found in borage at all stages was linoleic acid (C18:2n6) (19.1-23.7\%), followed by palmitic acid (C16:0) (17.1-18.0\%). These results are similar to Sayanova, Shewry, and Napier (1999), who noted that the fatty acids composition of borage flowers was characterized by having the highest content of linoleic (41.4\%) and palmitic (31.9\%) acids, although our values were lower.

In centaurea, oleic acid (C18:1) was the major fatty acid in tight buds (26.4\%), while in mature buds and fully open flowers, this was C16:0 (30.0 and 25.9\%, respectively). In petals, $\alpha$-linolenic acid (C18:3n3) was the prevalent fatty acid (27.7\%). However, C16:0, C18:1, and C18:3n3 acids were not significantly different $(p>0.05)$ during the flower development of centaurea. Furthermore, $\gamma$-linolenic (C18:3n6) and eicosenoic (C20:1) acids were not detected in centaurea, unlike borage. During the three stages of flowering, borage did not reported significant differences $(p>0.05)$ in the major fatty acids, with the exception of $\mathrm{C} 18: 3 \mathrm{n} 3$, which increased from 10.4 to $13.0 \%$. In all stages of development, PUFAs dominated over SFA in borage, followed by MUFA, due to the abundance of C18:2 and C18:3. Similar results were obtained by Peiretti et al. (2004), who reported that during the flower development of borage, high percentages of PUFA were detected between 65 and $80 \%$.

Contrastingly, in centaurea the following increasing order was observed: SFA > PUFA > MUFA, due to the contribution of C16:0, although SFA values were not very different from PUFA values. Furthermore, for the human diet, it is recommended that PUFA/SFA ratios be higher than 0.45 , and $n-6 / n-3$ ratios lower than 4.0 (Guil, Torija, Giménez, \& Rodriguez, 1996), which was observed in almost all stages of flowering, except in borage petals (PUFA/SFA $=0.40$ ), mature buds in centaurea (PUFA/SFA $=0.20$ ), and centaurea petals (PUFA/SFA $=0.44$ ). Thus, in general terms, both edible flowers at all flowering stages and petals had healthy lipid profiles.

\subsection{Vitamin $E$}

Free vitamin E was evaluated in all flowering stages, as detailed in Table 3. Results show that $\alpha$-tocopherol was the major compound in all samples, followed by $\gamma$-tocopherol in borage and $\beta$-tocopherol in centaurea. This richness in $\alpha$-tocopherol is important from a health perspective, since it represents a primary defense against lipid peroxidation (Bartoli, Simontacchi, Montaldi, \& Puntarulo, 1997), and such richness is similar to that found in other floral species such as calendula (Miguel et al., 2016; Pires et al., 2017), centaurea (Pires et al., 2017), 
Table 2

Fatty acid composition (relative \%) of borage and centaurea at three flowering stages.

\begin{tabular}{|c|c|c|c|c|c|c|c|c|}
\hline \multirow[t]{2}{*}{ Fatty acids (\%) } & \multicolumn{4}{|l|}{ Borage } & \multicolumn{4}{|l|}{ Centaurea } \\
\hline & Tight bud & Mature bud & Fully open & (Petals) & Tight bud & Mature bud & Fully open & (Petals) \\
\hline \multicolumn{9}{|l|}{ SFA } \\
\hline C12:0 & $0.5 \pm 0.2^{\mathrm{a}, \mathrm{b}, \mathrm{A}}$ & $0.6 \pm 0.2^{\mathrm{b}, \mathrm{A}}$ & $0.5 \pm 0.1^{\mathrm{a}, \mathrm{b}, \mathrm{A}}$ & $0.3 \pm 0.1^{\mathrm{a}, \mathrm{A}}$ & $0.7 \pm 0.2^{\mathrm{a}, \mathrm{A}}$ & $0.9 \pm 0.1^{\mathrm{a}, \mathrm{B}}$ & $0.6 \pm 0.2^{\mathrm{a}, \mathrm{A}}$ & $0.8 \pm 0.4^{\mathrm{a}, \mathrm{B}}$ \\
\hline C14:0 & $0.5 \pm 0.3^{\mathrm{a}, \mathrm{A}}$ & $0.8 \pm 0.3^{\mathrm{a}, \mathrm{A}}$ & $0.7 \pm 0.1^{\mathrm{a}, \mathrm{A}}$ & $2.1 \pm 0.1^{\mathrm{b}, \mathrm{B}}$ & $0.7 \pm 0.3^{\mathrm{a}, \mathrm{A}}$ & $1.0 \pm 0.5^{\mathrm{a}, \mathrm{A}}$ & $0.7 \pm 0.2^{\mathrm{a}, \mathrm{A}}$ & $0.7 \pm 0.3^{\mathrm{a}, \mathrm{A}}$ \\
\hline C15:0 & $0.2 \pm 0.1^{\mathrm{a}, \mathrm{A}}$ & $0.2 \pm 0.1^{\mathrm{a}, \mathrm{A}}$ & $0.2 \pm 0.1^{\mathrm{a}}$ & $0.4 \pm 0.1^{\mathrm{b}, \mathrm{B}}$ & $0.1 \pm 0.1^{\mathrm{a}, \mathrm{A}}$ & $0.2 \pm 0.2^{\mathrm{a}, \mathrm{A}}$ & nd & $0.2 \pm 0.2^{\mathrm{a}, \mathrm{A}}$ \\
\hline $\mathrm{C} 16: 0$ & $18.0 \pm 0.8^{\mathrm{a}, \mathrm{A}}$ & $17.8 \pm 0.9^{\mathrm{a}, \mathrm{A}}$ & $17.1 \pm 0.7^{\mathrm{a}, \mathrm{A}}$ & $17.2 \pm 0.1^{\mathrm{a}, \mathrm{A}}$ & $24.8 \pm 4.5^{\mathrm{a}, \mathrm{B}}$ & $30.0 \pm 1.2^{\mathrm{a}, \mathrm{B}}$ & $25.9 \pm 4.4^{\mathrm{a}, \mathrm{B}}$ & $25.2 \pm 4.2^{\mathrm{a}, \mathrm{B}}$ \\
\hline $\mathrm{C} 17: 0$ & $0.9 \pm 0.5^{\mathrm{a}, \mathrm{B}}$ & $1.0 \pm 0.1^{\mathrm{a}, \mathrm{A}}$ & $0.9 \pm 0.2^{\mathrm{a}, \mathrm{A}}$ & $1.3 \pm 0.1^{\mathrm{a}, \mathrm{A}}$ & $0.4 \pm 0.1^{\mathrm{a}, \mathrm{A}}$ & $1.2 \pm 0.3^{\mathrm{b}, \mathrm{c}, \mathrm{A}}$ & $0.6 \pm 0.3^{\mathrm{a}, \mathrm{b}, \mathrm{A}}$ & $1.3 \pm 0.6^{\mathrm{c}, \mathrm{B}}$ \\
\hline C18:0 & $4.9 \pm 0.4^{\mathrm{a}, \mathrm{A}}$ & $3.8 \pm 1.8^{\mathrm{a}, \mathrm{A}}$ & $4.8 \pm 0.4^{\mathrm{a}, \mathrm{A}}$ & $5.0 \pm 0.1^{\mathrm{a}, \mathrm{A}}$ & $5.8 \pm 1.1^{\mathrm{a}, \mathrm{A}}$ & $8.6 \pm 1.7^{\mathrm{a}, \mathrm{b}, \mathrm{B}}$ & $7.2 \pm 1.7^{\mathrm{a}, \mathrm{B}}$ & $10.6 \pm 3.2^{\mathrm{b}, \mathrm{B}}$ \\
\hline C20:0 & $1.5 \pm 0.8^{\mathrm{a}, \mathrm{A}}$ & $1.8 \pm 0.2^{\mathrm{a}, \mathrm{A}}$ & $1.8 \pm 0.2^{\mathrm{a}, \mathrm{A}}$ & $1.8 \pm 0.1^{\mathrm{a}, \mathrm{A}}$ & $2.5 \pm 0.8^{\mathrm{a}, \mathrm{A}}$ & $2.9 \pm 0.4^{\mathrm{a}, \mathrm{B}}$ & $2.5 \pm 0.7^{\mathrm{a}, \mathrm{B}}$ & $2.9 \pm 1.1^{\mathrm{a}, \mathrm{B}}$ \\
\hline $\mathrm{C} 22: 0$ & $2.4 \pm 0.7^{\mathrm{a}, \mathrm{B}}$ & $2.6 \pm 0.3^{\mathrm{a}, \mathrm{B}}$ & $2.5 \pm 0.4^{\mathrm{a}, \mathrm{A}}$ & $3.2 \pm 0.4^{\mathrm{a}, \mathrm{B}}$ & $1.2 \pm 0.4^{\mathrm{a}, \mathrm{A}}$ & $2.0 \pm 0.3^{\mathrm{a}, \mathrm{A}}$ & $1.4 \pm 0.5^{\mathrm{a}, \mathrm{B}}$ & $1.6 \pm 0.5^{\mathrm{a}, \mathrm{A}}$ \\
\hline $\mathrm{C} 24: 0$ & $2.4 \pm 1.3^{\mathrm{a}, \mathrm{A}}$ & $2.6 \pm 0.2^{\mathrm{a}, \mathrm{B}}$ & $2.6 \pm 0.3^{\mathrm{a}, \mathrm{B}}$ & $3.9 \pm 0.2^{\mathrm{b}, \mathrm{B}}$ & $1.3 \pm 0.5^{\mathrm{a}, \mathrm{A}}$ & $2.0 \pm 0.3^{\mathrm{a}, \mathrm{A}}$ & $1.6 \pm 0.6^{\mathrm{a}, \mathrm{A}}$ & $1.3 \pm 0.4^{\mathrm{a}, \mathrm{A}}$ \\
\hline Total SFA & 31.0 & 31.0 & 31.0 & 35.0 & 37.0 & 49.0 & 40.0 & 45.0 \\
\hline \multicolumn{9}{|l|}{ MUFA } \\
\hline $\mathrm{C} 16: 1$ & $0.1 \pm 0.1^{\mathrm{a}, \mathrm{A}}$ & $0.3 \pm 0.2^{\mathrm{a}}$ & $0.2 \pm 0.1^{\mathrm{a}, \mathrm{A}}$ & $0.2 \pm 0.1^{\mathrm{a}}$ & $0.2 \pm 0.1^{\mathrm{a}, \mathrm{A}}$ & nd & $0.3 \pm 0.2^{\mathrm{a}, \mathrm{B}}$ & nd \\
\hline C18:1 & $12.3 \pm 1.5^{\mathrm{a}, \mathrm{A}}$ & $10.3 \pm 7.7^{\mathrm{a}, \mathrm{A}}$ & $9.9 \pm 8.8^{\mathrm{a}, \mathrm{A}}$ & $6.7 \pm 1.2^{\mathrm{a}, \mathrm{A}}$ & $26.4 \pm 15.3^{\mathrm{a}, \mathrm{B}}$ & $9.04 \pm 3.45^{\mathrm{a}, \mathrm{A}}$ & $25.9 \pm 17.1^{\mathrm{a}, \mathrm{A}}$ & $19.8 \pm 18.5^{\mathrm{a}, \mathrm{B}}$ \\
\hline C20:1 & $0.4 \pm 0.2^{\mathrm{a}}$ & $0.6 \pm 0.4^{\mathrm{a}}$ & $0.3 \pm 0.0^{\mathrm{a}}$ & $0.5 \pm 0.1^{\mathrm{a}}$ & nd & nd & nd & nd \\
\hline C22:1 & $2.5 \pm 0.9^{\mathrm{a}, \mathrm{b}, \mathrm{B}}$ & $2.1 \pm 0.5^{\mathrm{a}, \mathrm{B}}$ & $1.8 \pm 0.2^{\mathrm{a}, \mathrm{B}}$ & $3.2 \pm 0.4^{\mathrm{b}, \mathrm{B}}$ & $0.7 \pm 0.5^{\mathrm{a}, \mathrm{A}}$ & $0.75 \pm 0.66^{\mathrm{a}, \mathrm{A}}$ & $0.9 \pm 0.8^{\mathrm{a}, \mathrm{A}}$ & $0.5 \pm 0.4^{\mathrm{a}, \mathrm{A}}$ \\
\hline $\mathrm{C} 24: 1 \mathrm{n} 9$ & $2.6 \pm 0.8^{\mathrm{a}, \mathrm{B}}$ & $2.2 \pm 0.3^{\mathrm{a}}$ & $2.0 \pm 0.3^{\mathrm{a}}$ & $3.5 \pm 0.3^{\mathrm{b}}$ & $0.1 \pm 0.1^{\mathrm{A}}$ & nd & nd & nd \\
\hline Total MUFA & 18.0 & 16.0 & 14.0 & 14.0 & 27.0 & 10.0 & 27.0 & 20.0 \\
\hline \multicolumn{9}{|l|}{ PUFA } \\
\hline C18:2n6 & $19.1 \pm 1.2^{\mathrm{a}, \mathrm{B}}$ & $21.3 \pm 1.5^{\mathrm{a}, \mathrm{b}, \mathrm{A}}$ & $21.2 \pm 2.2^{\mathrm{a}, \mathrm{b}, \mathrm{B}}$ & $23.7 \pm 0.8^{\mathrm{b}, \mathrm{B}}$ & $15.6 \pm 2.4^{\mathrm{b}, \mathrm{A}}$ & $20.7 \pm 3.0^{\mathrm{c}, \mathrm{A}}$ & $12.8 \pm 2.9^{\mathrm{a}, \mathrm{b}, \mathrm{A}}$ & $10.6 \pm 0.7^{\mathrm{a}, \mathrm{A}}$ \\
\hline C18:3n6 & $7.0 \pm 1.4^{\mathrm{a}}$ & $9.1 \pm 1.2^{\mathrm{b}}$ & $9.6 \pm 1.4^{\mathrm{b}}$ & $6.1 \pm 0.2^{\mathrm{a}}$ & nd & nd & nd & nd \\
\hline C18:3n3 & $10.4 \pm 1.7^{\mathrm{b}, \mathrm{A}}$ & $12.5 \pm 1.3^{\mathrm{b}, \mathrm{c}, \mathrm{A}}$ & $13.0 \pm 1.5^{\mathrm{c}, \mathrm{A}}$ & $8.2 \pm 0.7^{\mathrm{a}, \mathrm{A}}$ & $19.4 \pm 6.7^{\mathrm{a}, \mathrm{B}}$ & $20.3 \pm 2.2^{\mathrm{a}, \mathrm{B}}$ & $19.6 \pm 5.6^{\mathrm{a}, \mathrm{B}}$ & $27.7 \pm 7.8^{\mathrm{a}, \mathrm{B}}$ \\
\hline C18:4n3 & $5.9 \pm 1.1^{\mathrm{a}, \mathrm{b}}$ & $6.2 \pm 0.8^{\mathrm{b}, \mathrm{B}}$ & $6.5 \pm 0.8^{b}$ & $4.7 \pm 0.3^{\mathrm{a}, \mathrm{B}}$ & nd & $0.5 \pm 0.6^{\mathrm{a}, \mathrm{A}}$ & nd & $1.8 \pm 0.7^{\mathrm{b}, \mathrm{A}}$ \\
\hline $\mathrm{C} 22: 4 \mathrm{n} 6$ & $8.5 \pm 1.5^{\mathrm{b}}$ & $4.2 \pm 0.5^{\mathrm{a}}$ & $4.5 \pm 0.6^{\mathrm{a}, \mathrm{B}}$ & $8.4 \pm 0.3^{b}$ & nd & nd & $0.1 \pm 0.1^{\mathrm{A}}$ & nd \\
\hline Total PUFA & 51.0 & 53.0 & 55.0 & 51.0 & 35.0 & 42.0 & 32.0 & 35.0 \\
\hline PUFA/SFA & 0.58 & 0.52 & 0.45 & 0.40 & 0.73 & 0.20 & 0.68 & 0.44 \\
\hline $\mathrm{n} 6 / \mathrm{n} 3$ & 2.13 & 1.86 & 1.83 & 2.96 & 0.80 & 1.00 & 0.65 & 0.36 \\
\hline
\end{tabular}

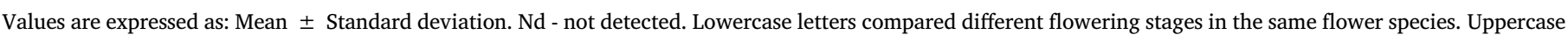
letters compared both flowers at the same flowering stage. Values with the same letter are not statistically different (p $>0.05$ ).

rose species (Guimarães et al., 2010; Pires et al., 2017), capper (Tlili, Nasri, Saadaoui, Khaldi, \& Triki, 2009), and lilium (Arrom \& MunnéBosch, 2010). In almost all flower development stages, borage showed a higher tocopherol content than centaurea; however, centaurea presented the highest value of $\alpha$-tocopherol in petals (3.47 mg/100 g dw), as well as higher $\beta$-tocopherol values than borage $(0.41-1.01$ vs $0.29-0.33 \mathrm{mg} / 100 \mathrm{~g} \mathrm{dw}$ ). No tocotrienols were detected in centaurea, while borage showed $\beta$ - and $\gamma$-tocotrienols in their composition in reduced amounts. Pires et al. (2017) also described the presence of $\alpha$ - and $\gamma$-tocopherols in centaurea flowers. Contrastingly, Lockowandt et al. (2019) did not detected $\beta$ - or $\delta$ - tocopherols in centaurea flowers, although the values for $\alpha$-tocopherol $(1.01 \mathrm{mg} / 100 \mathrm{~g} \mathrm{dw})$ and $\gamma$-tocopherol $(0.29 \mathrm{mg} / 100 \mathrm{~g} \mathrm{dw})$ were similar to ours.

Throughout flower development, the content of total tocopherols decreased in both flowers, between 3.7 and $3.2 \mathrm{mg} / 100 \mathrm{~g} \mathrm{dw}$ (borage) and 3.0 to $2.4 \mathrm{mg} / 100 \mathrm{~g} \mathrm{dw}$ (centaurea). However, borage and centaurea showed significant differences in individual tocols. In borage, $\alpha$ - and $\beta$-tocopherols decreased (from 2.75 to 2.21 and 0.33 to $0.29 \mathrm{mg}$ / $100 \mathrm{~g} \mathrm{dw}$, respectively) from tight bud to fully open stage, while $\gamma$-tocopherol increased (from 0.34 to $0.43 \mathrm{mg} / 100 \mathrm{~g} \mathrm{dw}$ ). In centaurea, the $\alpha$-tocopherol remained constant, while $\beta$ - and $\gamma$-tocopherols decreased (from 1.01 to 0.66 and 0.32 to $0.28 \mathrm{mg} / 100 \mathrm{~g} \mathrm{dw}$, respectively), indicating that different flowers had distinctive trends in vitamin $\mathrm{E}$ composition throughout flower development.

When analyzing caper from different Tunisian regions, Tlili et al. (2009) found that buds presented higher $\alpha$ - and $\gamma$-tocopherols values than flowers. An increase in $\alpha$-tocopherol content during the progression of senescence in chrysanthemum petals, followed by a decline in advanced stages (stage four - roughly $50 \%$ of full browning of the petal and evidence of wilting, and stage five - browning involved $50-100 \%$ of the petal), were been reported by Bartoli et al. (1997). In lilium floral organs, $\alpha$ - and $\gamma$-tocopherols also increased alongside the progression of

Table 3

Vitamin E contents (mg/100 $\mathrm{g} \mathrm{dw}$ ) in borage and centaurea at three flowering stages.

\begin{tabular}{|c|c|c|c|c|c|c|c|c|}
\hline \multirow[t]{2}{*}{ Tocols (mg/100 g) } & \multicolumn{4}{|l|}{ Borage } & \multicolumn{4}{|l|}{ Centaurea } \\
\hline & Tight bud & Mature bud & Fully open & (Petals) & Tight bud & Mature bud & Fully open & (Petals) \\
\hline$\alpha$-Tocopherol & $2.75 \pm 0.16^{\mathrm{c}, \mathrm{B}}$ & $2.24 \pm 0.05^{\mathrm{a}, \mathrm{A}}$ & $2.21 \pm 0.06^{\mathrm{a}, \mathrm{B}}$ & $2.47 \pm 0.11^{\mathrm{b}, \mathrm{A}}$ & $1.32 \pm 0.20^{\mathrm{a}, \mathrm{b}, \mathrm{A}}$ & $1.78 \pm 0.39^{\mathrm{b}, \mathrm{A}}$ & $1.24 \pm 0.01^{\mathrm{a}, \mathrm{A}}$ & $3.47 \pm 0.29^{\mathrm{c}, \mathrm{B}}$ \\
\hline$\beta$-Tocopherol & $0.33 \pm 0.01^{\mathrm{b}, \mathrm{A}}$ & $0.30 \pm 0.01^{\mathrm{a}, \mathrm{A}}$ & $0.29 \pm 0.01^{\mathrm{a}, \mathrm{A}}$ & $0.33 \pm 0.01^{\mathrm{b}, \mathrm{A}}$ & $1.01 \pm 0.07^{\mathrm{c}, \mathrm{B}}$ & $0.61 \pm 0.06^{\mathrm{b}, \mathrm{B}}$ & $0.66 \pm 0.07^{\mathrm{b}, \mathrm{B}}$ & $0.41 \pm 0.02^{\mathrm{a}, \mathrm{B}}$ \\
\hline$\gamma$-Tocopherol & $0.34 \pm 0.01^{\mathrm{a}, \mathrm{B}}$ & $0.43 \pm 0.01^{\mathrm{c}, \mathrm{B}}$ & $0.43 \pm 0.01^{\mathrm{c}, \mathrm{B}}$ & $0.38 \pm 0.02^{\mathrm{b}, \mathrm{A}}$ & $0.32 \pm 0.01^{\mathrm{b}, \mathrm{A}}$ & $0.34 \pm 0.04^{\mathrm{b}, \mathrm{A}}$ & $0.28 \pm 0.01^{\mathrm{a}, \mathrm{A}}$ & $0.39 \pm 0.01^{\mathrm{c}, \mathrm{A}}$ \\
\hline$\delta$-Tocoferol & $0.24 \pm 0.01^{\mathrm{a}, \mathrm{A}}$ & $0.25 \pm 0.01^{\mathrm{b}}$ & $0.24 \pm 0.01^{\mathrm{a}, \mathrm{A}}$ & $0.24 \pm 0.01^{\mathrm{a}, \mathrm{b}, \mathrm{A}}$ & $0.35 \pm 0.01^{\mathrm{b}, \mathrm{B}}$ & nd & $0.26 \pm 0.01^{\mathrm{a}, \mathrm{A}}$ & $0.34 \pm 0.03^{\mathrm{b}, \mathrm{B}}$ \\
\hline Total tocopherol & 3.7 & 3.2 & 3.2 & 3.4 & 3.0 & 2.7 & 2.4 & 4.6 \\
\hline$\beta$-Tocotrienol & $0.23 \pm 0.01^{\mathrm{b}}$ & $0.28 \pm 0.01^{\mathrm{c}}$ & $0.28 \pm 0.01^{c}$ & $0.22 \pm 0.01^{\mathrm{a}}$ & nd & nd & nd & nd \\
\hline$\gamma$-Tocotrienol & $0.23 \pm 0.01^{\mathrm{b}}$ & $0.20 \pm 0.01^{\mathrm{a}}$ & $0.19 \pm 0.01^{\mathrm{a}}$ & $0.25 \pm 0.01^{\mathrm{c}}$ & nd & nd & nd & nd \\
\hline Total tocotrienol & 0.5 & 0.5 & 0.5 & 0.5 & nd & nd & nd & nd \\
\hline
\end{tabular}

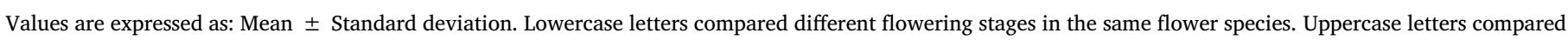
both flowers at the same flowering stage. Values with the same letter are not statistically different (p > 0.05). 
Table 4

Total and individual carotenoids in borage and centaurea at three flowering stages and petals.

\begin{tabular}{|c|c|c|c|c|}
\hline \multirow[t]{2}{*}{ Flowers } & \multirow[t]{2}{*}{ Flowering stages } & \multirow{2}{*}{$\frac{\text { Total carotenoids }}{\text { (mg } \beta \text {-carotene } / 100 \mathrm{~g} \mathrm{dw})}$} & $\beta$-carotene & Lutein \\
\hline & & & \multicolumn{2}{|l|}{ (mg $\beta$-carotene equivalent $/ 100 \mathrm{~g} \mathrm{dw}$ ) } \\
\hline \multirow[t]{4}{*}{ Borage } & Tight bud & $23.5 \pm 4.2^{\mathrm{b}, \mathrm{B}}$ & $0.45 \pm 0.03^{\mathrm{b}, \mathrm{B}}$ & $13.04 \pm 0.61^{\mathrm{b}, \mathrm{B}}$ \\
\hline & Mature bud & $23.8 \pm 0.1^{\mathrm{b}, \mathrm{B}}$ & $1.04 \pm 0.07^{\mathrm{c}, \mathrm{B}}$ & $14.95 \pm 0.32^{\mathrm{c}, \mathrm{B}}$ \\
\hline & Fully open & $181.4 \pm 13.9^{\mathrm{c}, \mathrm{B}}$ & $8.50 \pm 0.61^{\mathrm{d}, \mathrm{B}}$ & $43.73 \pm 2.24^{\mathrm{d}, \mathrm{B}}$ \\
\hline & (Petals) & $3.3 \pm 0.5^{\mathrm{a}, \mathrm{A}}$ & $0.04 \pm 0.01^{\mathrm{a}, \mathrm{A}}$ & $0.73 \pm 0.15^{\mathrm{a}, \mathrm{A}}$ \\
\hline \multirow[t]{4}{*}{ Centaurea } & Tight bud & $0.2 \pm 0.2^{\mathrm{a}, \mathrm{A}}$ & $0.002 \pm 0.001^{\mathrm{a}, \mathrm{A}}$ & $0.03 \pm 0.01^{\mathrm{a}, \mathrm{A}}$ \\
\hline & Mature bud & $7.8 \pm 0.3^{\mathrm{c}, \mathrm{A}}$ & $0.041 \pm 0.005^{\mathrm{b}, \mathrm{A}}$ & $1.16 \pm 0.06^{\mathrm{c}, \mathrm{A}}$ \\
\hline & Fully open & $5.8 \pm 1.0^{\mathrm{b}, \mathrm{A}}$ & $0.036 \pm 0.003^{\mathrm{b}, \mathrm{A}}$ & $1.08 \pm 0.03^{\mathrm{c}, \mathrm{A}}$ \\
\hline & (Petals) & $4.8 \pm 0.2^{\mathrm{b}, \mathrm{B}}$ & $0.091 \pm 0.039^{\mathrm{c}, \mathrm{B}}$ & $0.69 \pm 0.21^{\mathrm{b}, \mathrm{A}}$ \\
\hline
\end{tabular}

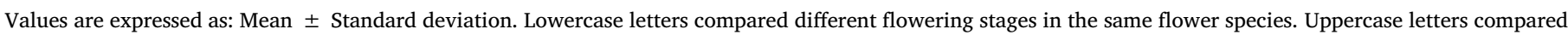
both flowers at the same flowering stage. Values with the same letter are not statistically different $(p>0.05)$.

tepal senescence, between stages one (closed flowers, with fully compacted organs and green tepals) and five (flowers with dehydrated tepals, just before abscission) (Arrom \& Munné-Bosch, 2010). It must be stated that centaurea petals were richer in $\alpha$ - and $\gamma$-tocopherols than the entire flower in each flowering stage. Thus, the consumption of borage and centaurea can contribute to the daily recommend dose of vitamin $\mathrm{E}$.

\subsection{Carotenoids}

The results for total and individual carotenoids are shown in Table 4. Carotenoids are pigments with provitamin and antioxidant roles. Regarding total carotenoids, borage always showed significantly higher amounts than centaurea at all stages of flower development (23.5-181.4 vs $0.2-7.8 \mathrm{mg} \beta$-carotene $/ 100 \mathrm{~g} \mathrm{dw}$ ), except in petals, where centaurea petals had a higher content than those of borage (4.8 and $3.3 \mathrm{mg}$ B-carotene $/ 100 \mathrm{~g} \mathrm{dw}$, respectively). This indicates that borage carotenoids are more prevalent in other flower components than in petals.

Regarding individual carotenoids, lutein was the main carotenoid in both flowers $(0.03-43.7 \mathrm{mg}$-carotene equivalent $/ 100 \mathrm{~g} \mathrm{dw})$, as in other edible flowers, namely: chrysanthemum (1.18-30.7 mg lutein/ $100 \mathrm{~g} \mathrm{dw}$ ) (Park et al., 2015), snapdragon (1.41 mg lutein/100 g dw) (González-Barrio et al., 2018), garden nasturtium (35.0-45.0 mg lutein/100 g fw) (Niizu \& Rodriguez-Amaya, 2005), marigold (106.2 mg lutein/100 g fw) (Tinoi, Rakariyatham, \& Deming, 2006), and pansies (5.11 mg lutein $/ 100 \mathrm{~g} \mathrm{dw}$ ) (González-Barrio et al., 2018). Borage presented consistently higher lutein contents than centaurea (0.73-43.73 vs $0.03-1.16 \mathrm{mg} \beta$-carotene equivalent $/ 100 \mathrm{~g} \mathrm{dw}$, respectively), except in petals, in which similar results were obtained $(0.73$ and $0.69 \mathrm{mg} \beta$ carotene equivalent $/ 100 \mathrm{~g} \mathrm{dw}$, respectively). $\beta$-carotene was also found in both flowers, but in much smaller amounts than lutein, ranging between 0.04 and $8.50 \mathrm{mg} \beta$-carotene equivalent $/ 100 \mathrm{~g} \mathrm{dw}$ for borage and between 0.002 and $0.091 \mathrm{mg} \beta$-carotene equivalent $/ 100 \mathrm{~g} \mathrm{dw}$ in centaurea.

Concerning flower development, different behavior was observed for each of the two flower species. Borage had the highest lutein concentration in the last flowering stage (fully open), with values three times higher than in previous stages, whereas centaurea presented an increase from tight to mature bud, and then a non-significant decrease to the fully open stage, but always in a very low range when compared to borage. Throughout borage flowering (tight bud to fully open stage), $\beta$-carotene also increased from $0.45-8.50 \mathrm{mg} \beta$-carotene $/ 100 \mathrm{~g} \mathrm{dw}$, while in centaurea it was almost residual, but remained more constant from mature bud to fully open flower. This different behavior between the flower species is also described in Ohmiya, Tanase, Hirashima, Yamamizo, and Yagi (2013), who detected that red carnation flowers accumulated small amounts of carotenoids at stage one (bud flower), followed by mature flower and decreased at stage four, i.e. - fully open flower; while in green carnations, the amount of carotenoids accumulated in petals during flower development (stage four). Yamamizo,
Kishimoto, and Ohmiya (2010) also detected a different behavior for petals of different species of Ipomoea during flowering development. In I. obscura and I. nil, the values of lutein and $\beta$-carotene decreased from stage one ( $12 \mathrm{~h}$ before flower opening) to stage four (fully opened flowers), while in Ipomoea sp. this content increased. Thus, each plant employs a different strategy for quantitatively and qualitatively controlling carotenoid levels in petals (Ohmiya et al., 2013).

Furthermore, carotenoids extracted from flowers can be used in the food, pharmaceutical, and cosmetics industries. In food industry, carotenoids can be used as a natural colorant, as is already the case; for example, the yellow color derived from the lutein of Tagetes erecta $\mathrm{L}$. flowers (Lin, Lee, \& Chang, 2015). On the other hand, some carotenoids are precursors of vitamins and also present actions that are anti-inflammatory, have antioxidant properties, immunomodulatory, and anti-cancer (Cardoso et al., 2017). As such, the inclusion in pharmaceutical and food products of these bioactive compounds in their concentrated form also represents an approach for promoting health. In fact, some dietary supplements, processed foods, beverages, confectionery, and dairy products already include carotenoids from flowers in their formulations (Berman et al., 2015).

\subsection{Organic acids}

The organic acids profiles of borage and centaurea during flowering development are presented in Table 5. Eight organic acids were detected, with distinct profiles for both flowers. In borage and centaurea, the total content of organic acids ranged between 6.1-9.2 and $8.6-14.4 \mathrm{~g} / 100 \mathrm{~g} \mathrm{dw}$, respectively. The major organic acid in borage was malic acid (2.09-4.66 g/100 g dw), followed by citric $(0.52-1.73 \mathrm{~g}$ / $100 \mathrm{~g} \mathrm{dw})$ and levulinic (0.69-1.58 g/100 g dw) acids. Contrastingly, in centaurea, the major organic acid was succinic acid (1.89-9.68 g/100 g $\mathrm{dw})$, followed by malic (1.47-2.17 g/100 g dw) and citric (1.09-2.76 g/ $100 \mathrm{~g} \mathrm{dw}$ ) acids. Petals had the highest total organic acid content, with different patterns in both flower species, but similar to those presented in flower development, with malic acid being prevalent in borage petals (50.6\%), and succinic acid in centaurea petals $(67.2 \%)$. Pires et al. (2017) also reported different organic acid profiles for dahlia, rose, calendula, and centaurea petals, for which the major organic acids were: malic acid $(0.74 \mathrm{~g} / 100 \mathrm{~g} \mathrm{dw})$, quinic and malic acids (1.52 and $1.23 \mathrm{~g} / 100 \mathrm{~g} \mathrm{dw}$, respectively), succinic acid (1.77 g/100 $\mathrm{g} \mathrm{dw}$ ), and oxalic acid $(0.18 \mathrm{~g} / 100 \mathrm{~g} \mathrm{dw})$, respectively. Furthermore, when analyzing dried centaurea petals (commercial sample), Pires et al. (2017) did not detect any of the current study's major organic acids, reporting only oxalic and shikimic acids. On the other hand, Lockowandt et al. (2019) also detected succinic (3.62 g/100 g dw), citric $(2.29 \mathrm{~g} / 100 \mathrm{~g}$ $\mathrm{dw})$, malic $(0.36 \mathrm{~g} / 100 \mathrm{~g} \mathrm{dw})$, and fumaric $(0.0021 \mathrm{~g} / 100 \mathrm{~g} \mathrm{dw})$ acids in fully open centaurea flowers, the first two organic acids being the dominant acids, in line with our results.

In both flowers, from tight bud to fully open stage, citric acid decreased (from 1.73-0.92 and $2.76-1.88 \mathrm{~g} / 100 \mathrm{~g}$ dw in borage and 
centaurea, respectively). In borage, levulinic and malic acids increased during flower development (0.69-1.17 and 2.09-2.88 g/100 g dw, respectively). In centaurea, succinic acid increased from tight bud $(1.89 \mathrm{~g} / 100 \mathrm{~g} \mathrm{dw})$ to fully open $(3.62 \mathrm{~g} / 100 \mathrm{~g} \mathrm{dw})$ stages, while malic acid decreased from $2.17-1.84 \mathrm{~g} / 100 \mathrm{~g}$ dw. Borage petals showed higher values for all organic acids quantified, except citric and salicylic acids. In centaurea petals, only succinic, hydroxycinnamic and malonic acids increased with flower development. Thus, food, cosmetics and pharmaceutic industries can use edible flowers as a new source of different organic acids, depending on the stage of flowering, as well as the part of the flower to be consumed (petals or whole flower).

Furthermore, malic and citric acids, which are important components in centaurea and borage flowers, have been reported to have protective effects on myocardial ischemia/reperfusion injury (Tang et al., 2013) and as having antimicrobial activity against some pathogenic microorganisms (Eswaranandam, Hettiarachchy, \& Johnson, 2004). Moreover, some of these organic acids are already used as food additives, such as citric acid, which demonstrated efficacy for pathogen control in fresh and processed meat (Anyasi, Jideani, Edokpayi, \& Anokwuru, 2017), or citric, malic, and tartaric acids as antioxidants in the manufacturing of beverages (Scherer et al., 2012).

\section{Conclusions}

In summary, the present work describes, for the first time, the chemical and nutritional composition of two edible flowers, centaurea and borage, at three flowering stages, and for their petals. Both flowers species have a high-water content (>73\%). In general, centaurea presented the highest values for total dietary fiber, while borage showed the highest protein, PUFA and total carotenoid content. During flowering, few changes were observed in the compounds analyzed for both flower species, the major differences detected being between flower and petals. In borage petals, the lowest protein and total carotenoid values were observed.

In conclusion, both edible flower species showed a nutritional composition and compounds with functional properties. Despite the lower amounts of some compounds, the daily consumption of edible flowers may contribute to supplying some macronutrients, vitamins, and organic acids to the human diet. These characteristics may therefore encourage the use of edible flowers (whole flower and petals) for human consumption.

\section{Acknowledgments}

The authors acknowledge the Portuguese Foundation for Science and Technology (FCT, Portugal) for the financial support provided by the research grant SFRH/BD/95853/2013 to Luana Fernandes and FCT/MEC for the financial support to QOPNA research Unit (FCT UID/ QUI/00062/2013) and LAQV Research Unit (UID/QUI/50006/2013 -POCI/01/0145/FEDER/007265) through national funds and co-financed by the FEDER, within the PT2020 Partnership Agreement. Furthermore, the authors are grateful to the Foundation for Science and Technology (FCT, Portugal) and FEDER under Programme PT2020 for financial support to CIMO (UID/AGR/00690/2013).

\section{References}

Amaral, J. S., Casal, S., Pereira, J. A., Seabra, R. M., \& Oliveira, B. P. P. (2003) Determination of sterol and fatty acid compositions, oxidative stability, and nutritional value of six walnut (Juglans regia L.) cultivars grown in Portugal. Journal of Agricultural and Food Chemistry, 51, 7698-7702.

Ammar, I., Ennouri, M., Bali, O., \& Attia, H. (2014). Characterization of two prickly pear species flowers growing in Tunisia at four flowering stages. LWT - Food Science and Technology, 59, 448-454.

Anyasi, T. A., Jideani, A. I. O., Edokpayi, J. N., \& Anokwuru, C. P. (2017). Application of organic acids in food preservation. In C. Vargas (Ed.). Biochemistry Research Trend. (pp. 1-47).

AOAC (1995). Official methods of analysis (16th ed.). Arlington, VA, USA: Association of 
Official Analytical Chemists.

AOAC (2003). Total dietary fiber in foods. Enzymatic-gravimetric method. Official methods of analysis of AOAC international(17th ed.). (985.29).

Arrom, L., \& Munné-Bosch, S. (2010). Tocopherol composition in flower organs of Lilium and its variations during natural and artificial senescence. Plant Science, 179, 289-295.

Aquino-Bolaños, E. N., Urrutia-Hernández, T. A., Castillo-Lozano, M. L. D., Chavéz-Servia, J. L., \& Verdalet-Guzmán, I. (2013). Physicochemical parameters and antioxidant compounds in edible squash (Cucurbita pepo) flower stored under controlled atmospheres. Journal of Food Quality, 36, 302-308.

Asadi-Samani, M., Bahmani, M., \& Rafieian-Kopaei, M. (2014). The chemical composition, botanical characteristic and biological activities of Borago officinalis: A review. Asian Pacific Journal of Tropical Medicine, 7(Suppl. 1), S22-S28.

Barros, L., Oliveira, S., Carvalho, A. M., \& Ferreira, I. C. F. R. (2010). In vitro antioxidant properties and characterization in nutrients and phytochemicals of six medicinal plants from the Portuguese folk medicine. Industrial Crops and Products, 32, 572-579.

Bartoli, C. G., Simontacchi, M., Montaldi, E. R., \& Puntarulo, S. (1997). Oxidants and antioxidants during aging of chrysanthemum petals. Plant Science, 129, 157-165.

Berman, J., Zorrilla-López, U., Farré, G., Zhu, C., Sandmann, G., Twyman, R. M., ... Christou, P. (2015). Nutritionally important carotenoids as consumer product. Phytochemistry Reviews, 14, 727-743.

Bieleski, R. L. (1993). Fructan hydrolysis drives petal expansion in the ephemeral daylily flower. Plant Physiology, 103, 213-219.

Cardoso, L. A. C., Karp, S. G., Vendruscolo, F., Kanno, K. Y. F., Zoz, L. I. C., \& Carvalho, J. C. (2017). Biotechnological production of carotenoids and their applications in food and pharmaceutical products. 126-141 Chapter 8.

Chaitanya, L. G. (2014). Food coloring: The natural way. Research Journal of Chemical Sciences, 4(2), 87-96.

Chen, Y., Zhu, Z., Guo, Q., Zhang, L., \& Zhang, X. (2012). Variation in concentrations of major bioactive compounds in Prunella vulgaris L. related to plant parts and phenological stages. Biological Research, 45, 171-175.

Cho, L.-H., Pasriga, R., Yoon, J., Jeon, J.-S., \& An, G. (2018). Roles of sugars in controlling flowering time. Journal of Plant Biology, 61, 121-130.

Cirak, C., Radusiene, J., Janulis, V., \& Ivanauskas, L. (2007). Secondary metabolites in Hypericum perfoliatum: Variation among plant parts and phenological stages. Botanica Helvetica, 117, 29-36.

Collier, D. E. (1997). Changes in respiration, protein and carbohydrates of tulip tepals and Alstroemeria petals during development. Journal of Plant Physiology, 150, 446-451.

Cruz, R., \& Casal, S. (2018). Direct analysis of vitamin A, vitamin E, carotenoids, chlorophylls and free sterols in animal and vegetable fats in a single normal-phase liquid chromatographic run. Journal of Chromatography A, 1565, 81-88.

Cruz, R., Casal, S., Mendes, E., Costa, A., Santos, C., \& Morais, S. (2013). Validation of a single-extraction procedure for sequential analysis of vitamin E, cholesterol, fatty acids, and total fat in seafood. Food Analytical Methods, 6, 1196-1204.

Dafny-Yelin, M., Guterman, I., Menda, N., Ovadis, M., Shalit, M., Pichersky, E., ... Vainstein, A. (2005). Flower proteome: Changes in protein spectrum during the advanced stages of rose petal development. Planta, 222, 37-46.

Dar, R. A., Tahir, I., \& Ahmad, S. S. (2014). Physiological and biochemical changes associated with flower development and senescence in Dianthus chinensis L. Indian Journal of Plant Physiology, 19(3), 215-221.

Del Baño, M. J., Lorente, J., Castillo, J., Benavente-García, O., Del Río, J. A., Ortuño, A., .. Gerard, D. (2003). Phenolic diterpenes, flavones, and rosmarinic acid distribution during the development of leaves, flowers, stems, and roots of Rosmarinus officinalis. Antioxidant activity. Journal of Agricultural and Food Chemistry, 51, 4247-4253.

Eswaranandam, S., Hettiarachchy, N. S., \& Johnson, M. G. (2004). Antimicrobial activity of citric, lactic, malic, or tartaric acids and nisin-incorporated soy protein film against Listeria monocytogenes, Escherichia coli 0157:H7, and Salmonella gaminara. Journal of Food Science, 69(3), 79-84.

Ferrara, L., Dosi, R., Di Maro, A., Guida, V., Cefarelli, G., Pacifico, S., ... Parente, A. (2011). Nutritional values, metabolic profile and radical scavenging capacities of wild asparagus (A. acutifolius L.). Journal of Food Composition and Analysis, 24, 326-333.

González-Barrio, R., Periago, M. J., Luna-Recio, C., Javier, G.-A. F., \& Navarro-González, I. (2018). Chemical composition of the edible flowers, pansy (Viola wittrockiana) and snapdragon (Antirrhinum majus) as new sources of bioactive compounds. Food Chemistry, 252, 373-380.

Guil, J. L., Torija, M. E., Giménez, J. J., \& Rodriguez, I. (1996). Identification of fatty acids in edible wild plants by gas chromatography. Journal of Chromatography A, 719, 229-235.

Guimarães, R., Barros, L., Carvalho, A. M., \& Ferreira, I. C. F. R. (2010). Studies on chemical constituents and bioactivity of Rosa micrantha: An alternative antioxidants source for food, pharmaceutical, or cosmetic applications. Journal of Agricultural and Food Chemistry, 58, 6277-6284.

http://ervasfinas.com/index_intro.php.

http://www.bloombites.nl/.

https://www.meadowsweetflowers.co.uk/.

https://www.petiteingredient.com.au/.

Husti, A., Cantor, M., Buta, E., \& Horţ, D. (2013). Current trends of using ornamental plants in culinary arts. ProEnvironment, 6, 52-58.

INSA (2010). Tabela de composição de alimentos. Lisboa - Portugal: Instituto Nacional de
Saúde Doutor Ricardo Jorge. Accessed in: http://portfir.insa.pt/.

Kumar, V., Sharma, A., Bhardwaj, R., \& Thukral, A. K. (2017). Analysis of organic acids of tricarboxylic acid cycle in plants using GC-MS, and system modeling. Journal of Analytical Science and Technology, 8(20), 1-9.

Lin, J.-H., Lee, D.-J., \& Chang, J.-S. (2015). Lutein production from biomass: Marigold flowers versus microalgae. Bioresource Technology, 184, 421-428.

Lockowandt, L., Pinela, J., Roriz, C. L., Pereira, C., Abreu, R. M. V., Calhelha, R. C., .. Ferreira, I. C. F. R. (2019). Chemical features and bioactivities of cornflower (Centaurea cyanus L.) capitula: The blue flowers and the unexplored non-edible part. Industrial Crops and Products, 128, 496-503.

Miguel, M., Barros, L., Pereira, C., Calhelha, R. C., Garcia, P. A., Ángeles, M. C., .. Ferreira, I. C. F. R. (2016). Chemical characterization and bioactive properties of two aromatic plants: Calendula officinalis L. (flowers) and Mentha cervina L. (leaves). Food Functions, 7, 2223-2232.

Mlcek, J., \& Rop, O. (2011). Fresh edible flower ornamental plants - A new source of nutraceutical foods. Trends in Food Science and Technology, 22, 561-569.

Moalem-Beno, D., Tamari, G., Leitner-Dagan, Y., Borochov, A., \& Weiss, D. (1997). Sugardependent gibberellin-induced chalcone synthase gene expression in Petunia corollas. Plant Physiology, 13, 419-424.

Niizu, P. Y., \& Rodriguez-Amaya, D. B. (2005). Flowers and leaves of Tropaeolum majus L. as rich sources of lutein. Journal of Food Science, 70, S605-S609.

Ohmiya, A., Tanase, K., Hirashima, M., Yamamizo, C., \& Yagi, M. (2013). Analysis of carotenogenic gene expression in petals and leaves of carnation (Dianthus caryophyllus L.). Plant Breeding, 132, 423-429.

Park, C. H., Chae, S. C., Park, S.-Y., Kim, J. K., Kim, Y. J., Chung, S. O., ... Park, S. U. (2015). Anthocyanin and carotenoid contents in different cultivars of chrysanthemum (Dendranthema grandiflorum Ramat.) flower. Molecules, 20 , 11090-11102.

Peiretti, P. G., Palmegiano, G. B., \& Salamano, G. (2004). Quality and fatty acid content of borage (Borago officinalis L.) during the growth cycle. Italian Journal of Food Science, $16,177-184$.

Pires, T. C. S. P., Dias, M. I., Barros, L., \& Ferreira, I. C. F. R. (2017). Nutritional and chemical characterization of edible petals and corresponding infusions: Valorization as new food ingredients. Food Chemistry, 220, 337-343.

Pirvu, L., Dragomir, C., Schiopu, S., \& Mihul, S. C. (2012). Vegetal extracts with gastroprotective activity. Part. I. Extracts obtained from Centaurea cyanus L. raw material Romanian Biotechnological Letters, 17(2), 7169-7176.

Reid, M. S. (2005). Flower development: From bud to bloom. Acta Horticulturae, 669, 105-110.

Rop, O., Mlcek, J., Jurikova, T., Neugebauerova, J., \& Vabkova, J. (2012). Edible flowers-A new promising source of mineral elements in human nutrition. Molecules, $17,6672-6683$.

Sayanova, O., Shewry, P. R., \& Napier, J. A. (1999). Characterization and expression of a fatty acid desaturase from Borago officinalis. Journal of Experimental Botany, 50, 411-412.

Scherer, R., Rybca, A. C. P., Ballus, C. A., Meinhart, A. D., Filho, J. T., \& Godoy, H. T. (2012). Validation of a HPLC method for simultaneous determination of main organic acids in fruits and juices. Food Chemistry, 135, 150-154.

Shahri, W., Tahir, I., Islam, S. T., \& Bhat, M. A. (2011). Physiological and biochemical changes associated with flower development and senescence in so far unexplored Helleborus orientalis Lam. cv. Olympicus. Physiology and Molecular Biology of Plants, 17, 33-39.

Sharma, A., Thakur, S., Kumar, V., Kanwar, M. K., Kesavan, A. K., Thukral, A. K., ... Ahmad, P. (2016). Pre-sowing seed treatment with 24-epibrassinolide ameliorates pesticide stress in Brassica juncea L. through the modulation of stress markers. Frontiers in Plant Science, 7, 1-12.

Silva, T. P. (2012). Fisiologia do desenvolvimento e senescência de flores de capuchinha (Tropaeolum majus L.). PhD Thesis. Universidade Federal de Viçosa http://www. locus.ufv.br/bitstream/handle/123456789/993/texto\%20completo.pdf? sequence $=1$.

Sood, S., Vyas, D., \& Nagar, P. K. (2006). Physiological and biochemical studies during flower development in two rose species. Scientia Horticulturae, 108, 390-396.

Sotelo, A., López-García, S., \& Basurto-Peña, F. (2007). Content of nutrient and antinutrient in edible flowers of wild plants in Mexico. Plant Foods for Human Nutrition, $62,133-138$.

Tang, X., Liu, J., Dong, W., Li, P., Li, L., Lin, C., ... Li, D. (2013). The cardioprotective effects of citric acid and L-malic acid on myocardial ischemia/reperfusion injury. Hindawi Publishing Corporation Evidence-based Complementary and Alternative Medicine11 820695.

Tinoi, J., Rakariyatham, N., \& Deming, R. L. (2006). Determination of major carotenoid constituents in petal extracts of eight selected flowering plants in the north of Thailand. Chiang Mai Journal of Science, 33, 327-334.

Tlili, N. S., Nasri, N., Saadaoui, E., Khaldi, A., \& Triki, S. (2009). Carotenoid and tocopherol composition of leaves, buds, and flowers of Capparis spinosa grown wild in Tunisia. Journal of Agricultural and Food Chemistry, 57, 5381-5385.

Tognetti, J. A., Pontis, H. G., \& Martinez-Noel, G. M. A. (2013). Sucrose signaling in plants. Plant Signaling \& Behavior, 8, e23316.

Yamamizo, C., Kishimoto, S., \& Ohmiya, A. (2010). Carotenoid composition and carotenogenic gene expression during Ipomoea petal development. Journal of Experimental Botany, 61, 709-719. 